Chirurgia (2020) 115: $579-584$

No. 5, September - October

Copyright@ Celsius

http://dx.doi.org/10.21614/chirurgia.115.5.579

\title{
Gynecological Benignities Causing Obstructive Uropathy. Review of the Literature
}

\author{
Angelos Peteinaris ${ }^{1}$, Athanasios Syllaios ${ }^{2}$, Dimitrios Schizas ${ }^{2}$, Spyridon Davakis ${ }^{2}$, Georgios Kalinterakis ${ }^{3}$, Zacharias \\ Fasoulakis ${ }^{4}$, Thomas Ntounis ${ }^{4}$, Nikolaos Garmpis ${ }^{2}$, Michail Diakosavvas ${ }^{4}$, Christos Kalfountzos ${ }^{5}$, Maria Andreadou ${ }^{5}$, \\ Pinelopi Papachatzopoulou ${ }^{6}$, Athanasios Chionis ${ }^{7}$, Nikolaos Thomakos ${ }^{4}$, Emmanuel N Kontomanolis ${ }^{8}$ and Antonios Koutras ${ }^{4}$
}

'Urology Department, Rio University Hospital, Patras, Greece

${ }^{2}$ First Department of Surgery, Laiko General Hospital, National and Kapodistrian University of Athens, Greece

${ }^{3}$ Department of Orthopedics, 401 Generally Military Hospital of Athens, Greece

${ }^{4}$ First Department of Obstetrics and Gynecology, Alexandra Maternity Hospital, National and Kapodistrian University of Athens, Greece

${ }^{5}$ Department of Surgery, General Hospital of Larisa, Larisa, Greece

${ }^{6}$ VVT AKMI, Larisa, Greece

${ }^{7}$ Department of Obstetrics and Gynecology, Laiko General Hospital, Athens, Greece

${ }^{8}$ Department of Obstetrics and Gynecology, Democritus University of Thrace, Alexandroupolis, Greece

${ }^{*}$ Corresponding author:

Spyridon Davakis MD

First Department of Surgery

Laiko General Hospital

National and Kapodistrian University

17 AgiouThoma Str., Athens, Greece

E-mail: spdavakis@gmail.com
Received: 16.08 .2020

Accepted: 14.10 .2020

\section{Rezumat}

Benignităti ginecologice care provoacă uropatie obstructivă. Trecere în revistă a literaturii de specialitate

Context/Scop: Uropatia obstructivă se caracterizează prin schimbarea caracteristicii structurale şi functionale a sistemului urinar datorită întreruperii scurgerii urinare normale. Benignitățile ginecologice ar putea provoca rareori uropatie obstructivă.

Material şi metode: În acest studiu a fost investigată incidența şi severitatea uropatiei obstructive cauzate de benignități ginecologice. În plus, am examinat spectrul procedurilor terapeutice, pentru a face față acestei afecțiuni clinice severe, precum şi a complicațiilor periculoase ale urosepsiei.

Rezultate: Benignitățile ginecologice pot provoca uropatie obstructivă. Aceste afecțiuni sunt rareori întâlnite, constituind o problemă dificilă pentru medici. În spectrul acestor afecțiuni sunt incluse masele de la nivelul anexelor uterine, leiomioamele, bolile inflamatorii pelvine şi endometrioza.

Concluzie:Uropatia obstructivă datorată benignităților ginecologice este o afecțiune foarte rară, dificilă şi provocatoare, iar medicii ar trebui să ia în considerare întotdeauna existența uropatiei în astfel de cazuri. 
Cuvinte cheie: uropatie obstructivă, benignități ginecologice, urosepsie, urologie, ginecologie

\begin{abstract}
Background/Aim: Obstructive uropathy is defined the clinical entity that is characterized by changing the structural and functional feature of the urinary system due to interruption of normal urinary runoff. Gynecological benignities could rarely cause obstructive uropathy.

Material and Methods:In this study the incidence and the severity of obstructive uropathy caused by gynecological benignities, was investigated. Additionally, we examined the spectrum of the contigent therapeutical procedures, in order to contend with this severe clinical entity, as well as the dangerous for life complication of urosepsis.

Results: Gynecological benignities can cause obstructive uropathy. These conditions are rarely faced, composing a challenging problem for physicians. In the spectrum of these conditions are included adnexal masses, leiomyomas, pelvic inflammatory disease and endometriosis.

Conclusion: Obstructive uropathy due to gynecological benignities is a very rare, difficult and challenging condition and physicians should always consider the existence of uropathy in such cases.
\end{abstract}

Key words: obstructive uropathy, gynecological benignities, urosepsis, urology, gynecology

\section{Introduction}

Obstructive uropathy is defined the clinical entity that is characterized by changing the structural and functional featureof the urinary system due to interruption of normal urinary runoff. It is a bewildering medical emergency that could be remarked at any level of the urinary tract. The urinary tract obstructions vary from partial to complete, mono to bilateral and acute to chronic and all these modifications subject to the origin, duration and severity of the obstructive cause (1).

A major consequence of obstructive uropathy is hydronephrosis. The term hydronephrosis means that the renal pelvis is dilatated and this medical condition could be detected by numerous imaging techniques. Among these, the gold standard in the diagnosis of obstructive uropathyis ultrasound (1).

Usually there are nonspecific symptoms of obstructive uropathy which vary depending on the time passed from the moment that the obstruction happened, as well as on how severe the obstruction is and its lateralization. The clinical symptoms include high fever with trembling, loin pain, lower urinary tract symptoms and urine retention. Furthermore, impaired renal function with uremic signs is a complicated symptom that requires immediate hospitalization and detailed treatment (2-4).

Urolithiasis, benign prostatic hypertrophy and congenital malformations constitute the main causes of hydronephrosis and of course of obstructive uropathy. Moreover other usual causes are advanced malignancies such as cervical, colorectal, prostate and bladder, because of the invasion and compression of the tumor to the ureters by primary or metastatic neoplasia. Periureteral fibrosis extends the invasion and compression mainly due to chemotherapy or radiation therapy $(5,6)$.

On the other hand, gynecological benignities could also rarely cause obstructive uropathy. The effect of these gynecological entities in this clinical situation has not been yet investigated in depth. These conditions are faced uncommonly and compose a challenging problem for the gynecologists. In the spectrum of these conditions are included adnexal masses, which involve the ovary, fallopian tube, or surrounding uterine ligaments, leiomyomas, pelvic inflammatory 
disease andendometriosis (7).

In this review we are going to investigate the incidence and the severity of obstructive uropathy caused by gynecological benignities, as current literature remains rather scarce on this topic. This clinical situation is extremely rare and current evidence is based only on a few case reports that are the only representative of this clinical situation in the published medical literature.Additionally we examined the spectrum of the contigenttherapeutical procedures in order to contend with this severe clinical entity as well as the dangerous for life complication of urosepsis.

\section{Obstructive Uropathy Due to Gynecological Benignities}

First of all, in the last years, there are some data indicating that gynecological benignities could cause obstructive uropathy. The incidence of the disease is increasing depending on the age of the patients. So the incidence of hydronephrosis in the general population is about $3,1 \%$, but it increases to $5,1 \%$ if the age spectrum is decreased to 60 years or older. Additionally the incidence in women is about $2,9 \%$, almost the half of mens' incidence, probably due to benign prostate hyperplasia. The $0,9 \%$ of the annual discharges of the US hospitals has the diagnosis of obstructive uropathy (8).

Probably the most common cause of obstructive uropathy due to benign gynecological lesions is endometriosis. This disease affects the urinary tract in $1 \%$ of all cases, although it is not common at all to affect the ureters alone. Ureteral endometriosis can be intrinsic or extrinsic. In the first occasion the pathological tissue is advanced in the lamina propria or tunica muscularis of the ureter and in the second occasion it is developed around the ureter, which refers to $80 \%$ of all cases $(9,10)$. In addition, due to its silent development it may result to a severe renal disease to $25-50 \%$ of all cases.Furthermore, it is really challenging for gynecologists and urologists to diagnose endometriosis due to the informality of the symptoms, as it is the cause for $32 \%$ of women who undergo laparoscopy due to chronic pelvic pain and unfortunately $1-7 \%$ of women are asymptomatic (11).

Hydronephrosis will gradually be eliminated after the surgical removal of the cause. If the patient has striking pain that does not decrease by systematic analgesia, high fever with shudder or affected kidney function, a percutaneous nephrostomy or a double $j$ stent should be placed in an urgent basis $(9-11)$.

\section{Cases of Obstructive Uropathy Due to Gynecological Benignities}

Kim HY et al. reported a 52-year-old woman with abdominal distention whose exams revealed a 36 × 21 × $30 \mathrm{~cm}$ cystic mass originating from the right ovary which caused not only the displacement of abdominal organs and kidneys, but also bilateral hydronephrosis and consequently obstructive uropathy. The patient underwent surgical excision of the mass. Pathological examination demonstrated a benign cystic lesion with hemorrhage and extensive thrombus formation. After surgical excision of the mass, contrast-enhanced abdominal CT urography showed partial the improvement of hydronephrosis (12).

Another interesting case of a 16-year-old female presented with a progressive abdominal distention. Her exams showed the existence of a multiseptated cystic mass in the abdomen measuring 22.5 × $30 \times 40.5 \mathrm{~cm}$, originating from the left ovary, which caused significant dilation of the intrahepatic ducts, the right renal pelvis and the proximal corresponding ureter. She underwent a laparoscopic left oophorectomy and the mass was a mature cystic teratoma (13).

Additionally, a similar case of a 24-year-old female attended the outpatient unit for her regular annual gynecological check-up. After her ultrasound assessment she was found with free liquid in the abdominal cavity and dilation of the right kidney pelvis. Moreover both her kidneys were found shrinked. An abdominal computed tomography was 
performed that revealed a $37 \mathrm{~cm}$ left adnexal cystic mass compressing the right proximal ureter and the right renal pelvis. The female underwent tumor resection of the left ovary, omentectomy and appendectomy. The histopathologic report revealed a benign ovarian serous papillary cystadenoma. The patient was discharged after two days. One year after the operation, no complications of surgical procedure or hydronephrosis are observed (14).

Another interesting case is this one regarding a 45-year-old female referring to an urologist by her general practitioner due to flank pain without fever and lower urinary tract symptoms. The intravenous urogram (IVU) demonstrated a $1 \mathrm{~cm}$ irregular radioopacity just below the left sacroiliac joint on the preliminary film and left hydronephrosis and hydroureter down and just medial to the level of the radio-opacity. After the placement of a double $j$ stent the characteristics of the pain changed and the patient underwent an abdominopelvic computed tomography that revealed a left ovarian dermoid cyst. She underwent exploratory laparotomy where oophorectomy was performed. The distal left ureter was compressed by the cyst which was excised. The histopathological examination confirmed the diagnosis of the computed tomography.Following oophorectomy, the patient's symptoms completely resolved (15).

Correira M. et al. reported the case of a 29year-old woman that presented for her annual routine check-up. The blood test laboratory analysis revealed an affected renal function (serum creatinine $2.86 \mathrm{mg} / \mathrm{dL}$ ). The patient underwent a renal ultrasound which revealed bilateral dilation, but normal parenchyma. The next diagnostic step was a computed tomography, which gave the suspicion of a mass with unknown origins. MRI suspended endometriosis. The patientunderwent explorative laparotomy, revealing a "frozen pelvis" due to endometriosis, confirmed histologically. Due to difficult resectability, a conservative approach was taken through hormonal treatment and bilateral ureteral pigtail placement, given the necessity to salvage renal function and decrease disease burden. Renal function was improved few days following surgery(16).

In addition to the previous case, another case of a 45-year-old female visited the emergency room with symptoms of acute dysuria, left flank pain with vomiting, nausea and generalized weakness for about seven days. She underwent transvaginal and kidney ultrasound that revealed a mass of about $5 \mathrm{~cm}$ in the left pelvic cavity and left hydronephrosis. After that the patient underwent a computed tomography that demonstrated the existence of a $4,5 \mathrm{~cm}$ mass originating from the left ovary, mild and severe hydronephrosis to the right and left kidney respectively. She underwent laparoscopic unilateral nephrectomy, cystectomy and double $\mathrm{J}$ catheter insertion. Histopathologic report revealed an endometrioma of the left ovary and ureteral endometriosis. Hydronephrosis resolved immediately.She had no complications and no evidence of endometriosis recurrence during 3-year follow-up at urology and gynecology outpatient departments and she was free from pain of endometriosis (17).

Muthuppalaniappan VM. et al. reported a 30-year-old female patient with an intrinsic endometriosis of the ureter. Her past medical history included systematic lupus erythematosus, an autoimmune condition that is connected with endometriosis. The patient presented for her annual check-up, when the blood test revealed the existence of renal dysfunction. The usual diagnostic work-up revealed the existence of bilateral intrinsic endometriosis of the ureters, which led to a severe left renal dysfunction. The patient underwent a bilateral re-implantantion of the ureters. The patient was totally asymptomatic and the existence of the disease was luckily discovered due to the patient's regular examination, because of her autoimmune status. Renal function improved slightly after surgery (18).

Also, Cramer D. et al. reported the case of a 44-year-old female that presented with a recurring left flank pain for the last 5 years. The patient underwent a renal ultrasound and a computed tomography that revealed the dilation of the left renal pelvis and a slight 
Table 1. Summary of studies presenting gynecological benignities causing obstructive uropathy

\begin{tabular}{lcll}
\hline Author & Age & Begningn situation that caused obstructive uropathy & Treatment \\
\hline Kim HY et al., 2016 & 52 & Cystic mass originating from the right ovary & Surgical excision of the mass \\
\hline Dolan MS et al., 2006 & 16 & Mature cystic teratoma & Laparoscopic left oophorectomy \\
\hline Pepaloza DAS et al., 2018 & 24 & Benign ovarian serous papillary cystadenoma & Surgical excision of the mass \\
\hline Aiken WD et al., 2015 & 45 & Left ovarian dermoid cyst & Surgical excision of the mass \\
\hline Correia Ml et al., 2017 & 29 & Endometriosis & $\begin{array}{l}\text { Double pigtail ureteral stenting } \\
\text { explorative laparotomy }\end{array}$ \\
\hline Tseng TY et al, 2009 & 45 & Endometrioma of the left ovary & Surgical excision of the mass \\
\hline Muthuppalaniappan VS et al., 2016 & 30 & Bilaterallntrinsic ureteral endometriosis & $\begin{array}{l}\text { Nephro-ureterectomybilateral re-implantention } \\
\text { of the ureters }\end{array}$ \\
\hline Lee HJ et al., 2017 & & & $\begin{array}{l}\text { Adhesiolysis, endometriosis excision, right } \\
\text { pigtail ureteral stenting }\end{array}$ \\
\hline
\end{tabular}

decrease of the parenchyma, without a diagnosis for the obstructive cause. A nuclear renal scan confirmed that her left kidney contributed only $24 \%$ to her renal function. After an ureteroscopy and a retrograde pyelography it was decided that the patient should undergo a left nephro-ureterectomy in order to roule out the existence of malignancy. The histopathologic results revealed the existence of endometrial tissue inside her left ureter (11).

On the contrary of the the two previous cases of intrinsic endometriosis of the ureters, it is reported a 44-year-old patient with a 4-year history of right-sided flank pain and renal pelvic dilation during menstruation. Despite several evaluations by physicians, including gynecologists, the cause of her symptoms was not diagnosed. The transvaginal US revealed the existence of a nodule at the right uterosacral ligament. The following MRI revealed a mass in the right uterineand a thickened wall of the right ureter. Right ureteral endometriosis was suspected. Diag-nostic laparoscopy revealed narrowing of the distal right ureter between the right utero-sacral ligament and the right ovary with adhesions caused by deep infiltrating endo-metriosis. The adhesion bands and infiltrating endometriosis around the right ureter were dissected. Extrinsic ureteral endometriosiswas diagnosed. Patients' symptoms resolved immediately after surgery (19).

All cases of obstructive uropathy originating from gynecological benignities are presented in Table 1.

\section{Conclusion}

In conclusion, hydronephrosis and obstructive uropathy due to gynecological benignities is a very rare, difficult and challenging condition, which involves at least two medical specialties and detailed examination of the patient. Clinicians and especially gynecologists and urologists should consider obstructive uropathy as a possible consequence of the presence of gynecological begninities and especially of ovarian cysts and endometriosis. Larger studies and case series are needed to fully elucidate the percentage of woman that are affected from this rare life-threatening condition.

\section{Conflict of Interest Statement}

The authors declare no potential conflict of interest.

\section{Funding Support}

There was no funding support for this study.

\section{Authors Contribution Statement}

Angelos Peteinaris: study conception, drafting of manuscript and analysis and interpretation of data; Athanasios Syllaios: drafting of manuscript and analysis and interpretation of data; Dimitrios Schizas: drafting of manuscript and analysis and interpretation of data; Spyridon Davakis: drafting of manuscript and analysis 
and interpretation of data; Georgios Kalinterakis: analysis and interpretation of data, drafting of manuscript; Zacharias Fasoulakis: analysis and interpretation of data, drafting of manuscript; Thomas Ntounis: analysis and interpretation of data, drafting of manuscript; Nikolaos Garmpis: analysis and interpretation of data, drafting of manuscript; Michail Diakosavvas: analysis and interpretation of data, drafting of manuscript; Maria Andreadou: analysis and interpretation of data, drafting of manuscript; Pinelopi Papachantzopoulou: analysis and interpretation of data, drafting of manuscript; Athanasios Chionis: analysis and interpretation of data, drafting of manuscript; Nikolaos Thomakos: analysis and interpretation of data, drafting of manuscript; Emmanuel N Kontomanolis: analysis and interpretation of data, drafting of manuscript; Antonios Koutras: study conception and design, acquisition of data and critical revision of manuscript.

\section{References}

1. Fiorini $F$, De Pascalis A, D'Amelio A, Di lorio B, Abaterusso $C$, Granata A. Native kidney ultrasound in obstructive uropathy. $G$ Ital Nefrol. 2020;37(1):2020-vol1. Italian

2. Van Aardt MC, Van Aardt J, Mouton A. Impact of percutaneous nephrostomy in South African women with advanced cervica cancer and obstructive uropathy. Southern African Journal of Gynaecological Oncology. 2017:9(1):6-10.

3. Perri T, Meller E, Ben-Baruch G, Inbar Y, Apter S, Heyman L, et al. Palliative urinary diversion in patients with malignant ureteric obstruction due to gynaecological cancer. BMJ Supportive \& Palliative Care. 2019;bmjspcare-2019-001771. Online ahead of print.

4. Lupu S, Brînza A, Socea B, Marcu D, Peride I, Stanescu AM A, et al. A brief review of the literature on the malignant ureteral obstruction. J Mind Med Sci. 2018;5(2):189-194.

5. Sountoulides P, Mykoniatis I, Dimasis N. Palliative management of malignant upper urinary tract obstruction. Hippokratia. 2014; 18(4):292-7.

6. Smith AP, Bazinet A, Liberman D. latrogenic ureteral injury after gynecological surgery. Can Urol Assoc J. 2019;13(6 Suppl4):S51-S55.

7. Boyle KJ, Torrealday S. Benign gynecologic conditions. Surg Clin North Am. 2008;88(2):245-64, v.

8. Tseng TY, Stoller ML. Obstructive uropathy. Clin Geriatr Med. 2009; 25(3):437-43.

9. Nezhat C, Falik R, McKinney S, King LP. Pathophysiology and management of urinary tract endometriosis. Nature Reviews Urology. 2017:14(6):359-72.

10. Ponticelli C, Graziani G, Montanari E. Ureteral endometriosis: A rare and underdiagnosed cause of kidney dysfunction. Nephron Clin Pract. 2010;114(2):C89-93.

11. Cramer DW, Missmer SA. The epidemiology of endometriosis. Ann N Y Acad Sci. 2002;955:11-22; discussion 34-6, 396-406.

12. Kim HY, Cho MK, Bae EH, Kim SW, Ma SK. Hydronephrosis caused by a giant ovarian cyst. Int Braz J Urol. 2016;42(4):848-9.

13. Dolan MS, Boulanger SC, Salameh JR. Laparoscopic management of giant ovarian cyst. JSLS. 2006;10(2):254-6.

14. Peñaloza DAS and Mendieta LCG. Hydronephrosis secondary to giant ovarian cystadenoma: report of a case. MOJ Anat \& Physiol. 2018;5(5):277-279

15. Aiken WD, Mayhew RG, Mitchell S, Stennett M, Johnson P. Ovarian dermoid cyst causing distal ureteral obstruction. West Indian Med J. 2015;64(2):157-9.

16. Correia MI, Gonçalves VP, Durăes AM, Santos JM, Rosa D, Nuno $G$, et al. Rare aetiology of obstructive kidney injury: Bilateral ureteral endometriosis. Port J Nephrol Hyper. 2017;31(1):47-49.

17. Choi JI, Yoo JG, Kim SJ, Lee HN and Kim MJ. Acute renal failure due to obstructive uropathy secondary to ureteral endometriosis. Case Rep Obstet Gynecol. 2015;2015:761348.

18. Muthuppalaniappan VS, Wiles KS, Mukerjee D, Abeygunasekara S. Silent obstruction in a young woman with systemic lupus erythematosus: a case report and literature review on kidney injury from ureteral endometriosis. Postgrad Med. 2016;128(3):307-10.

19. Lee HJ, Lee YS. Deep infiltrating ureteral endometriosis with catamenial hydroureteronephrosis: a case report. J Med Case Rep. 2017:11(1):346. 